\title{
Preference of farmers towards private and public extension services
}

\author{
Jasvinder Kaur*, Joginder S. Malik, P. S. Shehrawat, Sushila Dahiya a and Quadri \\ Javeed Ahmed Peer ${ }^{1}$
}

Department of Extension Education, ${ }^{a}$ Department of Sociology, CS Haryana Agricultural University, Hisar-125 004 (Haryana), INDIA

${ }^{1}$ Division of Extension Education, FOA, Wadura, Sher - E - Kashmir University of Agricultural Sciences and Technology of Kashmir-193 201 ( J\&K), INDIA

*Corresponding author e-mail: jasvinder.sidhu2012@gmail.com

Received: July 26, 2014; Revised received: September 26, 2014; Accepted: November 15, 2014

\begin{abstract}
The main purpose of this study was to know the preference of farmers for different services provided by private and public extension agencies. In recent times involvement of private extension agencies has been increased in agricultural sector and up to some extent it has sidelined the public extension agencies, but public extension agencies have potential to do better and to reach farmers at their best. In view of this, present study was undertaken to find out the farmers' preference towards public and private extension services in Ambala, Kurukshetra, Karnal, Hisar and Fatehabad districts of Haryana state. From each district two blocks were selected randomly and from each block two villages were selected. A manageable size of 10 farmers was selected from each village thus making total sample size of 200 farmers. Various aspects related to agricultural services provided by both public and private agencies were identified and response were obtained by putting a tick mark as per farmers' preference for private and public agencies. On the basis of statistical tools like rank and mean score, results showed that farmers had great preference for 'Input supply' in private extension as compared to public extension followed by 'Infrastructure facilities'. While for 'Consultancy and diagnosis services', 'Information' and 'Technical services', public extension was preferred as over the private extension.
\end{abstract}

Keywords: Agricultural services, Preference, Private extension, Public extension

\section{INTRODUCTION}

Agriculture is the backbone of Indian economy. To transfer the technology at farmers' field, extension education always played a pivotal role. But from recent times public extension system has become ineffective and correspondingly, there is emergence of some new actors like private extension agents in agricultural sector. All over the world agricultural extension assists the rural population of remote areas to uplift their living standard through increase in crop production (World Bank, 2003). Over the years, because of its valuable contribution to agricultural development, extension services became a public sector responsibility. Past investments in extension have yielded high economic rates of return and are seen as one reason for good global performance in food production (Alex et al., 2002). But there is an increasing realization that public extension by itself cannot meet the specific needs of various regions and different classes of farmers and policy environment will promote competitive private and community extension to operate effectively, in roles that complement, supplement, work in partnership and even substitute for public extension (DAC, 2000). The first and foremost reason behind privatization can be attributed to declining trends in governments' expenditures for extension in several countries over the last decades. Financial burden of government has forced to make sharp reduction in budgets of public extension programmes. Disappointing performance of public extension services, low coverage of public extension system, wide extension worker: farmer ratio, confined role of village extension worker, commercialization of agriculture and the existing market problems are some of the other reasons behind privatization of extension services in agriculture. A critical turning point occurred that affected the way information transfers (Olusola, 2011). Haryana is one of the agricultural advanced states of India. Because of rich profile in national agriculture, Haryana has become favourite destination for many private firms and these are getting involved in various farming aspects. Keeping this in view, the present study was undertaken to know the necessity of preferences of farmers before making any decision that whether private extension or existing public extension is good.

\section{MATERIALS AND METHODS}

The present study was conducted during 2012 in the 5 
districts namely: Ambala, Kurukshetra, Karnal, Fatehabad and Hisar of Haryana state. 2 blocks from each district were selected randomly. These were Saha and Barara blocks from Ambala district, Shahbad and Pehowa blocks from Kurukshetra district, Indri and Nilokheri blocks from Karnal district, Hisar-I and Hisar-II blocks from Hisar district and Tohana and Bhattu Kalan blocks from Fatehabad district. Hence, there was a total number of 10 blocks selected for the present investigation. Further, from each selected block, a list of all the villages was prepared and two villages from each block were selected by using simple random sampling technique. The villages so selected were Allahpur and Saha from Saha block, Mullana and Holi from Barara block, Mohindinpur and Bhukkar Majra from Shahbad block, Khiderpura and Behimajra from Pehowa block, Biana and Badarpur from Indri block, Padwala and Anjanthali from Nilokhedi block, Dabra and Gangwa from Hisar-I block, Kirtan and Dhiranwas from Hisar-II block, Akkanwali and Jamalpur Shekhion from Tohana block and Khabra Kalan and Dhabi Kalan from Bhattu Kalan block, respectively.

After that 10 farmers from each village has been selected to make the sample size of 200 respondents. The dictionary meaning of preference is 'favoring of one person etc., before othrs'.For the present study the term preference operationalised as the individual's inclination or choice among private and public extension for various kind of services. Five major dimensions of preferences, namely, information, consultancy and diagnosis, input supply, infrastructure, and technical services were identified. Each major aspect was sub divided and responses were obtained by putting a tick mark as per their preference for private or public agencies. Based on the findings, inferences were drawn. Tabulation and Quantification of data was done as per the standard procedure by using statistical tools viz. percentage, rank and mean score.

\section{RESULTS AND DISCUSSION}

Farmers' preference regarding 'information' provided by private and public extension services: It could be depicted from Table 1 that farmers preferred private extension services for ' $U p$ to date information related to technology' $($ mean $=1.32)$ followed by 'Access of electronic information' (mean=1.21) and 'Newly released and suitable varieties for area' (mean=0.75). This might be due to fact that private extension agents had more face to face contacts with farmers. Farmers were also frequently visits and interact with private dealers who acquainted them with latest information and technologies related to farming. While in case of public extension, they preferred services like 'Different aspects of cultivation including soil management, water management, weed management, storage, pest and disease management' (mean=0.96) followed by 'Information on credit, sources and formalities' (mean=0.92), 'Information on incentives' $($ mean $=0.92)$ and 'Prices of different commodities in different markets' (mean=0.83). Farmers regularly visit agricultural officers in the banks where they get information on credit, formalities and various incentives in agriculture. By different communication sources like radio and television they easily get information on prices of different commodities in different markets which are telecast daily on programs like Krishi Darshan and Kisan bhaiyo ke liye.

Farmers' preference regarding consultancy and diagnosis services of private and public extension services: It is clear from Table 2 that for 'Demand driven extension' (mean=1.14) farmers preferred private extension services followed by 'Advice on weed management' (mean=0.78) and 'Consultancy on prevention and cure of pest and disease problems' (mean= 0.54) which might be due to the fact that private extension agencies are having more face to face contact with farmers and input dealers also work as consultant so when the farmers go for purchasing the inputs they could also get advice on prevention and cure of pest and disease problems at the same place. In public extension farmers 'Advice on quality of soil, water, fertilizers, seeds etc.' (mean $=1.08$ ), 'Expertise for the diagnosis of pest and diseases' $($ mean $=1.01$ ) and 'Advice on weed management' (mean $=0.88$ ) were preferred in ascending order might be due to its credibility.

Farmers' preference regarding input supply of private and public extension services: Table 3 revealed that from private extension, farmers preferred different kind of inputs like 'High yielding varieties of different crops' (mean=1.33), 'Seedling for plantation crops' $\quad($ mean=1.31) and 'Insecticide/pesticide/ weedicide' (mean=1.10). These results were supported by studies of Singh and Narain (2008a) who reported that 67.00 per cent of farmers purchased pesticide from different private agencies and in case of seeds of vegetables, fodder and seedlings of fruits, forest trees, private was preferred over public extension agencies. In public extension farmers preferred 'Different kind of spray pumps'(mean 0.72) and 'Fertilizers' (mean 0.58) might be due to the fact that farmers could get subsidy on spray pumps by government which were sold by agriculture department and they could get surety for the quality of fertilizer which they purchase from co-operative society. While in case of 'High yielding varieties of different crops' they preferred both agencies but more preference was given to private extension agencies due to adequate availability.

Farmers' preference regarding infrastructure facilities of private and public extension services: Results from Table 4 showed that for 'Cold storage facilities' (mean=1.11), 'Store house facilities' (mean=0.91) and 'Packing and processing units' (mean $=0.86$ ) farmers preferred private extension. This might be due 
Table 1. Farmers' preference regarding information provided by private and public extension services $(n=200)$.

\begin{tabular}{|c|c|c|c|c|c|}
\hline \multirow{2}{*}{$\begin{array}{c}\text { S. } \\
\text { No. }\end{array}$} & \multirow[t]{2}{*}{ Aspects } & \multicolumn{2}{|c|}{ Private extension } & \multicolumn{2}{|c|}{ Public extension } \\
\hline & & Mean & Rank & Mean & Rank \\
\hline 1. & Up to date information related to technology & 1.32 & $\mathrm{I}$ & 0.56 & $\mathrm{~V}$ \\
\hline 2. & Access of electronic information & 1.21 & II & 0.43 & VI \\
\hline 3. & Newly released and suitable varieties for area & 0.75 & III & 0.78 & IV \\
\hline 4. & $\begin{array}{l}\text { Different aspects of cultivation including soil management, } \\
\text { water management, weed management, storage, pest and } \\
\text { disease management }\end{array}$ & 0.72 & IV & 0.96 & I \\
\hline 5. & Prices of different commodities in different markets & 0.34 & V1 & 0.83 & III \\
\hline 6. & Information on credit, sources and formalities & 0.18 & III & 0.92 & II \\
\hline 7. & Information on incentives & 0.13 & II & 0.92 & II \\
\hline
\end{tabular}

Table 2. Farmers' preference regarding consultancy and diagnosis services of private and public extension services $(n=200)$.

\begin{tabular}{|c|c|c|c|c|c|}
\hline \multirow{2}{*}{$\begin{array}{c}\text { S. } \\
\text { No. }\end{array}$} & \multirow{2}{*}{ Aspect } & \multicolumn{2}{|c|}{ Private extension } & \multicolumn{2}{|c|}{ Public extension } \\
\hline & & Mean & Rank & Mean & Rank \\
\hline 1 & Demand driven extension & 1.14 & I & 0.37 & $\mathrm{~V}$ \\
\hline 2 & Advice on weed management & 0.78 & II & 0.88 & III \\
\hline 3 & $\begin{array}{l}\text { Consultancy on prevention and cure of pest and } \\
\text { disease problems }\end{array}$ & 0.54 & III & 0.65 & IV \\
\hline 4 & Solution to specific problems & 0.52 & IV & 0.37 & $\mathrm{~V}$ \\
\hline 5 & Expertise for the diagnosis of pest and diseases & 0.42 & $\mathrm{~V}$ & 1.01 & II \\
\hline 6 & Advice on quality of soil, water, fertilizers, seeds etc. & 0.29 & VI & 1.08 & I \\
\hline
\end{tabular}

Table 3. Farmers' preference regarding input supply of private and public extension services $(n=200)$.

\begin{tabular}{|c|c|c|c|c|c|}
\hline \multirow{2}{*}{$\begin{array}{c}\text { S. } \\
\text { No }\end{array}$} & \multirow[t]{2}{*}{ Aspect } & \multicolumn{2}{|c|}{ Private extension } & \multicolumn{2}{|c|}{ Public extension } \\
\hline & & Mean & Rank & Mean & Rank \\
\hline 1 & High yielding varieties of different crops & 1.33 & $\bar{I}$ & 0.54 & III \\
\hline 2 & Seedling for plantation crops & 1.31 & II & 0.31 & VI \\
\hline 3 & Insecticide/pesticide/weedicide & 1.10 & III & 0.52 & IV \\
\hline 4 & Fertilizers & 0.95 & IV & 0.58 & II \\
\hline 5 & Latest agricultural tools and implements & 0.64 & $\mathrm{~V}$ & 0.50 & $\mathrm{~V}$ \\
\hline 6 & Different kinds of spray pumps & 0.51 & VI & 0.72 & I \\
\hline
\end{tabular}

Table 4. Farmers' preference regarding infrastructure facilities of private and public extension services $(n=200)$.

\begin{tabular}{llcccc}
\hline S. No. & Aspects & \multicolumn{2}{c}{ Private extension } & \multicolumn{2}{c}{ Public extension } \\
\cline { 3 - 6 } & & Mean & Rank & Mean & Rank \\
\hline 1 & Cold storage facilities & 1.11 & I & 0.54 & V \\
2 & Store house facilities & 0.91 & II & 0.83 & II \\
3 & Packing and processing units & 0.86 & III & 0.62 & IV \\
4 & Transportation facilities & 0.68 & IV & 0.64 & III \\
5 & Laboratory & 0.52 & V & 0.93 & I \\
\hline
\end{tabular}

to that private agencies provide more facilities like cleanliness, fans, coolers and proper ventilation to keep farmers' produce safe. Many big private agencies are getting involved in post harvest technologies and processing units. While for services like 'Laboratory' (mean=0.93) and 'Store house facilities' (mean=0.83) public extension was found more preferred because of its accessibility to farmers.

Farmers' preference regarding technical services of private and public extension services: Table 5 revealed that for 'Value addition to crop produce' $($ mean $=0.96)$, 'Biofertilizers/ biopesticides, livestock management practices' (mean $=0.85$ ) and 'Machineries on rent and repair' (mean $=0.70$ ) farmers preferred private extension services because these services are widely in the hands of private extension. In case of other technical services like 'Soil and water testing facilities' (mean $=1.02)$, 'Forecast pest and disease problems' $($ mean $=0.80)$ and 'Soil health (structure and fertility management, enhancement)' (mean= 0.69) farmers preferred public extension. This result can be supported by that the public extension services 
Table 5. Farmers' preference regarding technical services of private and public extension services $(n=200)$.

\begin{tabular}{llcccc}
\hline \multicolumn{2}{c}{ S. } & Aspects & \multicolumn{2}{c}{ Private extension } & \multicolumn{2}{c}{ Public extension } \\
\cline { 2 - 6 } No. & & Mean & Rank & Mean & Rank \\
\hline 1 & Value addition to crop produce & 0.96 & I & 0.36 & VI \\
2 & Biofertilizers/ biopesticide, livestock & 0.85 & II & 0.50 & IV \\
& management practices & & & & \\
3 & Machineries on rent and repair & 0.70 & III & 0.45 & V \\
4 & Forecast pest and disease problems & 0.50 & IV & 0.80 & II \\
5 & Soil and water testing facilities & 0.28 & V & 1.02 & I \\
6 & Soil health (structure and fertility management, & 0.25 & VI & 0.69 & III \\
& enhancement) & & & & \\
\hline
\end{tabular}
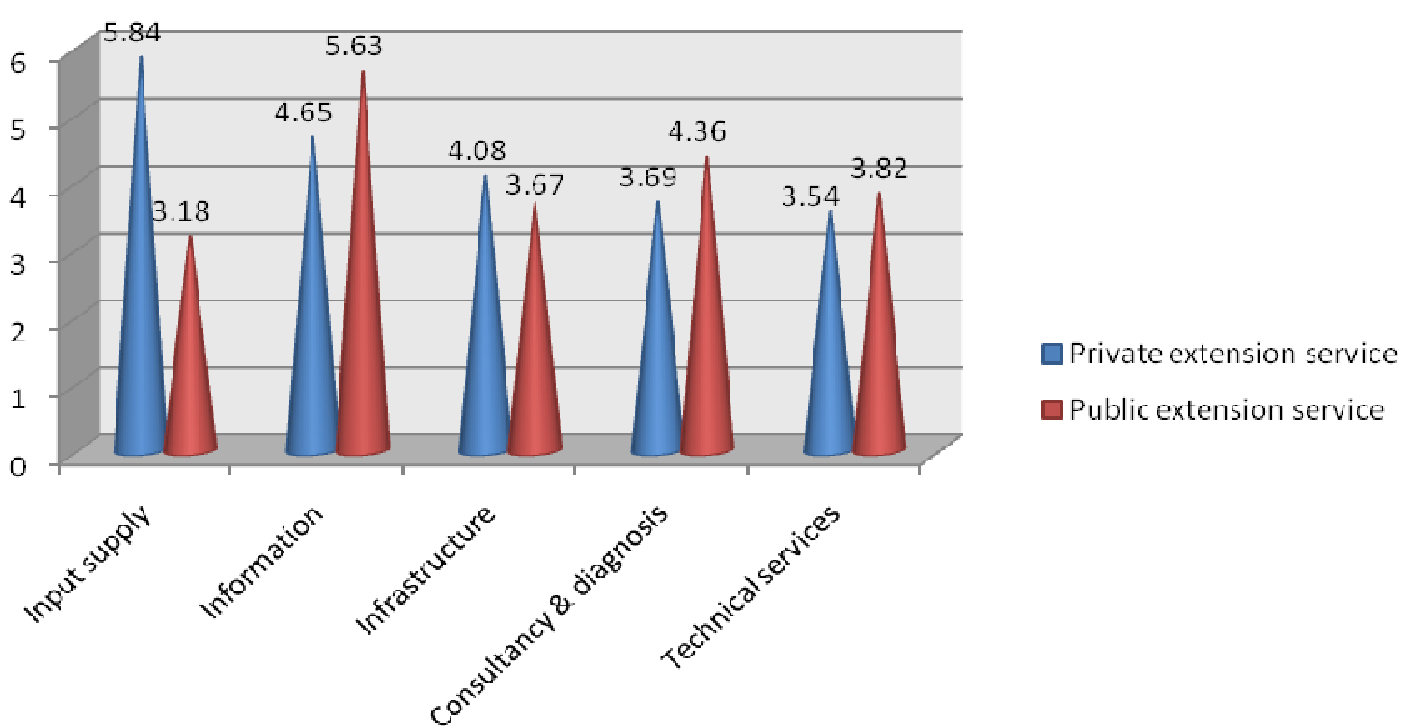

Fig. 1. Comparison of overall preference (mean score) among farmers towards private and public extension services.

like soil and water testing and weather forecasting had high authenticity among farmers. These results are in line with those of Mercy (2008) who conducted a study on privatization in Mali and reported that soil fertility improvement was generally done by the public (80\%) extension officers.

Overall preference among farmers towards private and public extension services: Data presented in Fig. 1 give the results about preference of farmers for various aspects towards private and public extension services. Results from Fig. 1 emphasize that farmers preferred private extension $($ mean $=5.84)$ as compared to public extension (mean=3.18) for 'Input supply', while in case of 'Information' they preferred public extension $($ mean $=5.63)$ over the private extension $($ mean $=4.65)$.

Further, for 'Infrastructure' they preferred private extension (mean=4.08) as compared to public extension (mean =3.67). For 'Consultancy and diagnosis' farmers preferred public extension $($ mean $=4.36)$ over the private extension $($ mean= 4.36$)$ and the same results were obtained for 'Technical services' for which farmers also preferred public extension (mean=3.82) as compared to private extension (mean= 3.54). Results are in same line with those of Singh and Narain (2008b) who in their study conducted in Kanpur observed that 76.00 per cent farmers were ready to pay for 'advice on plant protection measures' followed by 63.00 per cent farmers willing to pay for 'advice on weed management' and 60.00 per cent for 'livestock management'. The willingness of farmers to pay for advisory services was found depending upon severity.

\section{Conclusion}

It was concluded that for various inputs like High Yielding Varieties (HYV); seedlings; insecticide/ pesticide/ weedicide and infrastructure facilities of cold storage, store house, value addition and transportation farmers preferred private extension services. Overall preference among farmers towards private and public extension services showed that input supply and infrastructure facilities were preferred in the private extension (mean=5.84 and 4.08) over the public extension (mean=3.18 and 3.676), while for information, consultancy and diagnosis and technical services, public extension $($ mean $=5.63,4.36$ and 3.82) was more preferred over the private extension (mean=4.65, 3.69 and 3.54). Both private and public extension agencies should come together for 
disseminating the useful technologies effectively to the end-users for their overall development.

\section{REFERENCES}

Alex, G., Zijp, W. and Byerlee, D. (2002). Rural extension and advisory services : New directions. Rural Strategy Background Paper, No. 9. Washington, D.C. AKIS Thematic Team, World Bank.

DAC (2000). Policy framework for agricultural extension (draft). New Delhi : Extension Division, Department of Agriculture and Co-operation, Ministry of Agriculture, Government of India.

Mercy, Akeredolu O. (2008). Private sector involvement in agricultural extension service delivery in Mali :Views and constraints from the Pilot Phase. Proceedings of the 24th Annual Meeting. E.A.R.T.H. University, Costa Rica:1-14

Olusola, S.A. (2011). Farmers' perception on public and private extension services on south-western Nigeria. Ph.D . Thesis, University of Ilorin.

Singh, A.K. and Narain, S. (2008a). Effectiveness of public and private extension system in delivering services. Indian Research Journal of Extension Education. 8 (2 \& 3) : 29-31.

Singh, A.K and Narain, S. (2008b). Capacity and willingness of farmers to pay for extension. Indian Research Journal of Extension Education. 8 (2\&3) : 51-54.

World Bank (2003). Operationalizing Agricultural Extension Reforms in South Asia : A Case of Pakistan. Country Paper : Regional Workshop, Delhi, India. 